\title{
Evaluation of the Effect of Naringenin on Pentylenetetrazole and Maximal Electroshock-Induced Convulsions in Mice
}

\author{
Mohammad Javad Khodayar, ${ }^{1,2,3,}$ Saeed Salehi, ${ }^{1}$ Mohsen Rezaei, ${ }^{4}$ Amir Siahpoosh, ${ }^{2,5}$ Ahad Khazaei, \\ and Gholamreza Houshmand ${ }^{1}$ \\ ${ }^{1}$ Department of Toxicology, School of Pharmacy, Ahvaz Jundishapur University of Medical Sciences, Ahvaz, IR Iran \\ ${ }^{2}$ Medicinal Plants and Natural Products Research Center, Ahvaz Jundishapur University of Medical Sciences, Ahvaz, IR Iran \\ ${ }^{3}$ Toxicology Research Center, Ahvaz Jundishapur University of Medical Sciences, Ahvaz, IR Iran \\ ${ }^{4}$ Department of Toxicology, Faculty of Medical Sciences, Tarbiat Modares University, Tehran, IR Iran \\ ${ }^{5}$ Department of Pharmacognosy, School of Pharmacy, Ahvaz Jundishapur University of Medical Sciences, Ahvaz, IR Iran \\ "Corresponding author: Mohammad Javad Khodayar, Department of Toxicology, School of Pharmacy, Ahvaz Jundishapur University of Medical Sciences, Ahvaz, IR Iran. E-mail: \\ jkhodayar@yahoo.com
}

Received 2015 August 02; Revised 2016 July 07; Accepted 2016 September 13.

\begin{abstract}
Background: Naringenin is a flavonoid with several different biological effects in central nervous system. As mentioned, naringenin has neuroprotective, memory enhancing, anti-inflammatory and antioxidant effects.

Objectives: In this study, we investigated effects of naringenin on pentylenetetrazole and maximal electroshock-induced seizures in mice.

Methods: Naringenin was administered at doses of 50,100 and $200 \mathrm{mg} / \mathrm{kg}$ intraperitoneally in two models of seizure. Thirty minutes after different doses of naringenin, phenytoin or diazepam and vehicle, the animal received pentylenetetrazole or current stimulus by an electroconvulsiometer.

Results: In maximal electroshock model, naringenin $200 \mathrm{mg} / \mathrm{kg}$ reduced the duration of hind limb tonic extension. In pentylenetetrazole seizure model all doses of naringenin increased the latency for convulsion and latency for Straub's tail but only naringenin $200 \mathrm{mg} / \mathrm{kg}$ showed significant reduction in duration of myoclonic seizure.

Conclusions: According to the results, naringenin showed significant anticonvulsant and neuroprotection activity in two pentylenetetrazole and electroshock models of convulsion in mice and these effects may be mediated by antioxidant properties, agonist activity on $\mathrm{GABA}_{\mathrm{A}}$ receptors and weakening of glutamate transmission.
\end{abstract}

Keywords: Naringenin, Pentylenetetrazole, Maximal Electroshock, Convulsion, Mice

\section{Background}

Epilepsy is a chronic neurological disorder by recurrent, spontaneous seizures (1). Epilepsy is described as a complex neurological dysfunction and it affects 50 million people around the world (2). The cause of epilepsy is often unknown, although it may progress after brain attack, such as trauma, tumor growth, infection or other types of neurological disorders (3). Current antiepileptic drugs are effective in controlling seizures in $70 \%$ of cases. Side effects such as chronic toxicity and teratogenicity have limited the use of anticonvulsant drugs (4, $5)$. Thus, recently herbal medicines have played an important role in human health and preclinical evaluation for seizures or recognized mechanisms of action that are related to epilepsy (6). Flavonoids are a class of naturally polyphenolic compounds present in a broad variety of human nutriment and possess a wide range of biological effects including a variety of neuroprotective activities (7). The biological effects of flavonoids, including those on the brain, have been recognized to be related to their antioxidant actions (8). Naringenin (4',5,7-trihydroxyflavanone), a dietary flavonoid in fruits and vegetables such as grapefruit, tomato and orange has been reported to have a number of biological effects, such as neuroprotective (9) and mono amine oxidase inhibitory (10), anti-inflammatory as well as antioxidant (11) and memory enhancing activity (12). It has been suggested that neuroprotective effects of naringenin in experimental stroke is mediated by suppression of NF- $\kappa$ B-mediated neuroinflammation (13). Furthermore, naringenin was found to be a neuroprotective agent in Parkinson's disease, amnesia, Alzheimer's disease and prevents oxidative injury in numerous pathophysiological disorders due to their ability to cross into the brain (14-16).

\section{Objectives}

According to previous researches, this study was designed to investigate the effects of naringenin on 
Pentylenetetrazole (PTZ) and Maximal Electroshock (MES)induced seizures in mice.

\section{Methods}

\subsection{Experimental Animals}

Male C57 albino mice, born and reared in the research center and experimental animal house of Ahvaz Jundishapur University of Medical Sciences, were used in the present study. Young healthy male mice (21 - $25 \mathrm{~g}$ ) were housed and maintained at $23 \pm 2{ }^{\circ} \mathrm{C}$ under laboratory conditions with alternating food and water except for a short time when they were removed from their cages for testing. The animals were fasted two hours before and during the test. Animal care was carried out in accordance with institutional guidelines for animal care and use, and all possible measures were taken to minimize the number of animals used and their suffering, including immediate euthanasia after acute experiments. Each mouse was used only once. Animals were adapted to the new environment for at least one hour before testing.

\subsection{Drugs and Chemicals and Solutions}

Naringenin (Sigma-Aldrich, USA), PTZ (Sigma-Aldrich, USA), Phenytoin (HIDANTIC, Caspian Tamin, Iran) and diazepam (ZEPADIC, Caspian Tamin, Iran) were used in the present study. All chemicals were dissolved in $0.9 \%$ saline except naringenin, which was dissolved in $0.1 \%$ Carboxy Methyl Cellulose (CMC). Drug solutions were prepared fresh.

\subsection{Maximal Electroshock-Induced Seizures Test}

Mice were divided to five groups each containing six animals and treated with either vehicle, naringenin (50, 100 or $200 \mathrm{mg} / \mathrm{kg}$, i.p.) or phenytoin ( $25 \mathrm{mg} / \mathrm{kg}$, i.p.). Thirty minutes later, seizures were induced by a current stimulus ( $50 \mathrm{~mA}, 80 \mathrm{~Hz}$ for 0.2 second) delivered through using ear electrodes by an electroconvulsiometer (Borjsanat Company, Iran). In order to improve electrode contact, the electrodes were moistened with normal saline before being attached to the ears of mice. The current used was predetermined before experimentation and was the current that caused Hind-Limb Extension (HLTE) in all control mice in the trials. The duration of HLTE (i.e., the hind limbs of animals outstretched at $180^{\circ}$ to the plane of the body axis) was recorded $(17,18)$. In this method of MES convulsion no death occurred.

\subsection{Pentylenetetrazole-Induced Seizures Test}

Mice were divided to five groups each containing six animals and received either vehicle naringenin $(50,100$ or $200 \mathrm{mg} / \mathrm{kg}$, i.p.) or diazepam (1 mg/kg, i.p.). Thirty minutes later, seizures were induced by pentylenetetrazole ( 85 $\mathrm{mg} / \mathrm{kg}$, i.p.). The animals were observed during the first 30 minutes for latency of convulsion, latency for Straub's tail, duration of myoclonic and protection of mortality.

\subsection{Statistical Analysis}

All the results are expressed as mean \pm Standard Deviation (SD). Latency to induce seizures, latency to straub's tail and myoclonic duration in PTZ model and HLTE in MES model were analyzed by One-way Analysis Of Variance (ANOVA) followed by post hoc Tukey's test comparison. $\mathrm{P}$ values of $<0.05$ were considered statistically significant.

\section{Results}

4.1. Effect of Naringenin on Maximal Electroshock-Induced Seizures

In the MES model, $200 \mathrm{mg} / \mathrm{kg}$ of naringenin significantly reduced the duration of hind limb tonic extension compared to the untreated group. However, phenytoin completely prevented hind limb tonic extension (Table 1 ).

\subsection{Effect of Naringenin on PTZ-Induced Seizures}

In PTZ-induced seizures, administration of naringenin at doses of 50,100 and $200 \mathrm{mg} / \mathrm{kg}$ increased the latency for convulsion and latency for straub's tail compared to the negative control group, vehicle $(\mathrm{P}<0.001)$, yet only 200 $\mathrm{mg} / \mathrm{kg}$ of naringenin decreased the duration of myoclonic in mice $(\mathrm{P}<0.05)$. In addition, naringenin and diazepam showed significant protection against mortality as well as seizures. Whereas diazepam-treated $(1 \mathrm{mg} / \mathrm{kg}$, i.p.) animals failed to show any signs of convulsions and all mice were protected from PTZ-induced convulsions (Table 2).

\section{Discussion}

In present study, anticonvulsant activity of naringenin was demonstrated in two pentylenetetrazole and electroshock models of convulsion. In MES-induced seizure model, naringenin $200 \mathrm{mg} / \mathrm{kg}$ decreased HLTE duration as compared to the vehicle group. Phenytoin anticonvulsant effects on MES was mediated by blocking the voltage-gated sodium and calcium channels (19). Considering the impact of drugs on general and complex seizures induced by MES (20), naringenin can be raised for improvement of this type of seizure. In PTZ-induced seizure model, the lowest mortality and reduction in duration of myoclonic 
Table 1. Effect of Naringenin on Maximal Electroshock-Induced Seizures in Mice ${ }^{\mathrm{a}, \mathrm{b}}$

\begin{tabular}{lccc}
\hline Treatment & Dose $(\mathbf{m g} / \mathbf{k g})$ & N & Hind Limb Tonic Extensions $($ sec $)$ \\
\hline Vehicle & $10 \mathrm{~mL} / \mathrm{kg}$ & 6 & $18.62 \pm 1.15$ \\
Phenytoin & 25 & 6 & $0 \pm 0^{\mathrm{c}}$ \\
NAR 50 & 50 & 6 & $6.99 \pm 0.49$ \\
NAR 100 & 100 & 6 & $17.00 \pm 1.68$ \\
NAR 200 & 200 & $68.87 \pm 1.36^{\mathrm{d}}$ \\
\hline
\end{tabular}

${ }^{\mathrm{a}}$ Values are expressed as mean $\pm \mathrm{SD}$. Data were analyzed by one-way ANOVA followed by Tukey - HSD multiple comparison test

${ }^{\mathrm{b}} \mathrm{F}(4,25)=258.7 ; \mathrm{P}<0.001$

${ }^{c} \mathrm{P}<0.001$ as compared to vehicle group.

${ }^{\mathrm{d}} \mathrm{P}<0.01$.

Table 2. Effect of Naringenin on PTZ-Induced Seizures in Mice $e^{a, b, c, d}$

\begin{tabular}{|c|c|c|c|c|c|c|}
\hline Treatment & Dose (mg/kg) & $\mathbf{N}$ & $\begin{array}{l}\text { Latency for Convulsion } \\
\text { (sec) }\end{array}$ & $\begin{array}{l}\text { Latency for Straub's Tail } \\
\text { (sec) }\end{array}$ & $\begin{array}{l}\text { Duration of Myoclonic } \\
\text { (sec) }\end{array}$ & $\begin{array}{l}\text { Protection of Mortality } \\
\text { (sec) }\end{array}$ \\
\hline Vehicle & $10 \mathrm{ml} / \mathrm{kg}$ & 6 & $65.52 \pm 2.48$ & $90 \pm 2$ & $11.54 \pm 0.51$ & $0 / 6(0.00)$ \\
\hline Diazepam & 1 & 6 & $1280.2 \pm 26.58^{\mathrm{e}}$ & $1800 \pm 0^{\mathrm{e}}$ & $0 \pm 0^{e}$ & $6 / 6(100.00)$ \\
\hline NAR 50 & 50 & 6 & $428.17 \pm 7.67^{\mathrm{e}}$ & $438.17 \pm 3.06^{\mathrm{e}}$ & $11.73 \pm 0.49$ & $2 / 6(33.33)$ \\
\hline NAR 100 & 100 & 6 & $535.83 \pm 5.81^{\mathrm{e}}$ & $568 \pm 5.93^{\mathrm{e}}$ & $10.46 \pm 1.16$ & $3 / 6(50.00)$ \\
\hline NAR 200 & 200 & 6 & $797.2 \pm 5.80^{\mathrm{e}}$ & $828.6 \pm 4.61^{\mathrm{e}}$ & $9.78 \pm 1.30^{f}$ & $4 / 6(66.67)$ \\
\hline
\end{tabular}

${ }^{\mathrm{a}}$ Values are expressed as mean \pm SD. Data were analyzed by one-way ANOVA followed by Tukey-HSD multiple comparison test.

${ }^{\mathrm{b}} \mathrm{F}(4,25)=6591.799 ; \mathrm{P}<0.001$ (Latency for convulsion).

${ }^{\mathrm{C}} \mathrm{F}(4,25)=47674.494 ; \mathrm{P}<0.001$ (Latency for Straub's tail).

${ }^{d} \mathrm{~F}(4,25)=204.779 ; \mathrm{P}<0.001$ (Duration of myoclonic).

${ }^{\mathrm{e}} \mathrm{P}<0.001$ as compared vehicle group.

${ }^{\mathrm{f}} \mathrm{P}<0.05$

seizures was obtained with the $200 \mathrm{mg} / \mathrm{kg}$ dose. Thus, this dose was introduced as the most effective dose in PTZinduced seizures. Clinically effective drugs against PTZinduced seizure could be used in treatment of myoclonic and absence epilepsy (21-23). Accordingly, naringenin can be effective in absence epilepsy. This study is the first report of naringenin in improvement of convulsion in animal models. Thus, there are no available researches for comparison with the current study. One of the most common causes of seizures in humans and animals is decreasing the GABAergic and increasing of glutamatergic system activity. The $\mathrm{GABA}_{\mathrm{A}}$ receptors are ligand-gated ion channels, which mediate the most common inhibitory transmission in synapses. The $\mathrm{GABA}_{\mathrm{A}}$ receptor function not only prevents the development of epilepsy, but also inhibits the development of convulsive activity throughout the cerebral cortex tissues (24). Pentylenetetrazole mediates convulsive behavior through blocking of $\mathrm{GABA}_{\mathrm{A}}$ receptors, which are present in the membrane of neurons in the central nervous system. This blocking effect can trigger transmission of glutamatergic system. Therefore, the drugs which are agonists for $\mathrm{GABA}_{\mathrm{A}}$ can prevent PTZ-induced seizure. Block- ing of $\mathrm{GABA}_{\mathrm{A}}$ receptor gated chloride channels and triggering glutamate transmission increase influx of calcium ions, which led to an increase in production of superoxide radicals. The evidences showed that flavonoids have antianxiety and anticonvulsant effects by binding to the benzodiazepine binding site on GABA receptors in the central nervous system $(25,26)$. In a study for evaluating naringin protection against kainic acid-induced status epilepticus, the results showed that pretreatment with naringin significantly increased the latency of seizures as compared to the vehicle treated group. Accordingly, naringin has therapeutic potential for preventing kainic acid-induced seizures (27). Naringin is hydrolyzed to a major metabolite, naringenin, which readily crosses the blood brain barrier $(28,29)$. Thus one of the possible mechanisms of naringenin to inhibit the effects of PTZ is weakening of glutamatergic neurotransmission. Oxidative stress and mitochondrial dysfunction can make seizure attacks on brain that lead to the production of free radicals and oxidative damage to proteins, lipids and nucleic acid $(30,31)$. The free radicals aggravate epilepsy through inhibition of glutamine synthase and consequently increase brain gluta- 
mate level (32). Thus, oxidative stress is known as one of the leading causes of seizures. It seems that antioxidants such as flavonoids can inhibit pentylenetetrazole-induced seizures by reducing oxidative stress (33). Flavonoids such as naringenin can increase the antioxidant activity in the body and enhances the activity of antioxidant enzymes that reduce the production of oxygen free radicals, and tissue damage $(34,35)$. In conclusion, the results of naringenin anticonvulsant effects in both models of convulsion in mice suggest that the neuroprotective effects of naringenin may be mediated by antioxidant properties, agonist activity on $\mathrm{GABA}_{\mathrm{A}}$ receptors and weakening of glutamate transmission.

\section{References}

1. Gourie-Devi M, Gururaj G, Satishchandra P, Subbakrishna DK. Prevalence of neurological disorders in Bangalore, India: a communitybased study with a comparison between urban and rural areas. $\mathrm{Neu}$ roepidemiology. 2004;23(6):261-8. doi: 10.1159/000080090. [PubMed: 15297791].

2. de Boer HM, Mula M, Sander JW. The global burden and stigma of epilepsy. Epilepsy Behav. 2008;12(4):540-6. doi: 10.1016/j.yebeh.2007.12.019. [PubMed: 18280210].

3. Leonard BE. Fundamentals of psychopharmacology. John Wiley \& Sons; 2004

4. Smith MC, Bleck TP. Convulsive disorders: toxicity of anticonvulsants. Clin Neuropharmacol. 1991;14(2):97-115. [PubMed: 2015616].

5. Rang HP, Ritter JM, Flower RJ, Henderson G. Rang \& Dale's Pharmacology: With student consult online access. Elsevier Health Sciences; 2014.

6. Schachter SC. Botanicals and herbs: a traditional approach to treating epilepsy. Neurotherapeutics. 2009;6(2):415-20. doi: 10.1016/j.nurt.2008.12.004. [PubMed: 19332338].

7. Vafeiadou K, Vauzour D, Lee HY, Rodriguez-Mateos A, Williams RJ, Spencer JP. The citrus flavanone naringenin inhibits inflammatory signalling in glial cells and protects against neuroinflammatory injury. Arch Biochem Biophys. 2009;484(1):100-9. doi: 10.1016/j.abb.2009.01.016. [PubMed: 19467635].

8. Rice-Evans CA, Miller NJ, Paganga G. Structure-antioxidant activity relationships of flavonoids and phenolic acids. Free Radic Biol Med. 1996;20(7):933-56. [PubMed: 8743980].

9. Zbarsky V, Datla KP, Parkar S, Rai DK, Aruoma OI, Dexter DT. Neuroprotective properties of the natural phenolic antioxidants curcumin and naringenin but not quercetin and fisetin in a 6-OHDA model of Parkinson's disease. Free Radic Res. 2005;39(10):1119-25. doi: 10.1080/10715760500233113. [PubMed: 16298737].

10. Olsen HT, Stafford GI, van Staden J, Christensen SB, Jager AK. Isolation of the MAO-inhibitor naringenin from Mentha aquatica $\mathrm{L}$. J Ethnopharmacol. 2008;117(3):500-2. doi: 10.1016/j.jep.2008.02.015. [PubMed: 18372132].

11. Shi Y, Dai J, Liu H, Li RR, Sun PL, Du Q, et al. Naringenin inhibits allergen-induced airway inflammation and airway responsiveness and inhibits NF-kappaB activity in a murine model of asthma. Can J Physiol Pharmacol. 2009;87(9):729-35. doi: 10.1139/y09-065. [PubMed: 19794524].

12. Spencer JP. Food for thought: the role of dietary flavonoids in enhancing human memory, learning and neuro-cognitive performance. Proc Nutr Soc. 2008;67(2):238-52. doi: 10.1017/S0029665108007088. [PubMed: 18412998].

13. Raza SS, Khan MM, Ahmad A, Ashafaq M, Islam F, Wagner AP, et al. Neuroprotective effect of naringenin is mediated through sup- pression of NF-kappaB signaling pathway in experimental stroke. Neuroscience. 2013;230:157-71. doi: 10.1016/j.neuroscience.2012.10.041. [PubMed: 23103795].

14. Baluchnejadmojarad $T$, Roghani M. Effect of naringenin on intracerebroventricular streptozotocin-induced cognitive deficits in rat: a behavioral analysis. Pharmacology. 2006;78(4):193-7. doi 10.1159/000096585. [PubMed: 17065836].

15. Mercer LD, Kelly BL, Horne MK, Beart PM. Dietary polyphenols protect dopamine neurons from oxidative insults and apoptosis: in vestigations in primary rat mesencephalic cultures. Biochem Pharmacol. 2005;69(2):339-45. doi: 10.1016/j.bcp.2004.09.018. [PubMed: 15627486]

16. Heo HJ, Kim MJ, Lee JM, Choi SJ, Cho HY, Hong B, et al. Naringenin from Citrus junos has an inhibitory effect on acetylcholinesterase and a mitigating effect on amnesia. Dement Geriatr Cogn Disord. 2004;17(3):151-7. doi: 10.1159/000076349. [PubMed: 14739537].

17. Luszczki JJ, Glowniak K, Czuczwar SJ. Time-course and dose-response relationships of imperatorin in the mouse maximal electroshock seizure threshold model. Neurosci Res. 2007;59(1):18-22. doi: 10.1016/j.neures.2007.05.004. [PubMed: 17602770].

18. Sayyah M, Mandgary A, Kamalinejad M. Evaluation of the anticonvulsant activity of the seed acetone extract of Ferula gummosa Boiss. against seizures induced by pentylenetetrazole and electroconvulsive shock in mice. J Ethnopharmacol. 2002;82(2):105-9.

19. Sitges M, Chiu LM, Reed RC. Effects of Levetiracetam, Carbamazepine, Phenytoin, Valproate, Lamotrigine, Oxcarbazepine, Topiramate, Vinpocetine and Sertraline on Presynaptic Hippocampal $\mathrm{Na}(+)$ and $\mathrm{Ca}(2+)$ Channels Permeability. Neurochem Res. 2016;41(4):758-69. doi: 10.1007/s11064-015-1749-0. [PubMed: 26542150].

20. Loscher W, Fassbender CP, Nolting B. The role of technical, biological and pharmacological factors in the laboratory evaluation of anticonvulsant drugs. II. Maximal electroshock seizure models. Epilepsy Res. 1991;8(2):79-94. [PubMed: 2065646].

21. Peterson SL. Glycine potentiation of anticonvulsant drugs in pentylenetetrazol seizures in rats. Brain Res Bull. 1991;26(1):43-7. [PubMed: 2015517].

22. Loscher W, Honack D, Fassbender CP, Nolting B. The role of technical, biological and pharmacological factors in the laboratory evaluation of anticonvulsant drugs. III. Pentylenetetrazole seizure models. Epilepsy Res. 1991;8(3):171-89. [PubMed: 1907909].

23. Namvaran AA, Tavakkoli GF. The effect of Salvia officinalis hydroalcoholic extract on PTZ-induced seizure threshold in Vincristine injected mice. 2012 ;13:47-55.

24. Fisher A, Walker M, Bowery N. Mechanisms of action of antiepileptic drugs. In: Ander JW, Walker MC, Smalls JE, editors. Epilepsy: From synapse to society. A practical guide to epilepsy.. Crowborough: Meritus Communications; 2003. pp. 249-72.

25. Jager AK, Gauguin B, Adsersen A, Gudiksen L. Screening of plants used in Danish folk medicine to treat epilepsy and convulsions.J Ethnopharmacol. 2006;105(1-2):294-300. doi:10.1016/j.jep.2005.10.015. [PubMed 16293381].

26. Salah SM, Jager AK. Screening of traditionally used Lebanese herbs for neurological activities. J Ethnopharmacol. 2005;97(1):145-9. doi: 10.1016/j.jep.2004.10.023. [PubMed: 15652288].

27. Golechha M, Chaudhry U, Bhatia J, Saluja D, Arya DS. Naringin protects against kainic acid-induced status epilepticus in rats: evidence for an antioxidant, anti-inflammatory and neuroprotective intervention. Biol Pharm Bull. 2011;34(3):360-5. [PubMed: 21372385].

28. Ribeiro IA, Rocha J, Sepodes B, Mota-Filipe H, Ribeiro MH. Effect of naringin enzymatic hydrolysis towards naringenin on the antiinflammatory activity of both compounds. J Mol Catal B Enzym. 2008;52:13-8.

29. Rice-Evans C. Flavonoid antioxidants. Curr Med Chem. 2001;8(7):797807. [PubMed: 11375750 ]. 
30. Jesberger JA, Richardson JS. Oxygen free radicals and brain dysfunction. Int J Neurosci. 1991;57(1-2):1-17. [PubMed: 1938149].

31. Kunz WS. The role of mitochondria in epileptogenesis. Curr Opin Neurol. 2002;15(2):179-84. [PubMed: 11923632].

32. Oliver CN, Starke-Reed PE, Stadtman ER, Liu GJ, Carney JM, Floyd RA. Oxidative damage to brain proteins, loss of glutamine synthetase activity, and production of free radicals during ischemia/reperfusion-induced injury to gerbil brain. Proc Natl Acad Sci U S A. 1990;87(13):5144-7. [PubMed: 1973301].

33. Ilhan A, Gurel A, Armutcu F, Kamisli S, Iraz M. Antiepileptogenic and antioxidant effects of Nigella sativa oil against pentylenetetrazol- induced kindling in mice. Neuropharmacology. 2005;49(4):456-64. doi:10.1016/j.neuropharm.2005.04.004. [PubMed:15913671].

34. Ghanim H, Mohanty P, Pathak R, Chaudhuri A, Sia CL, Dandona P. Orange juice or fructose intake does not induce oxidative and inflammatory response. Diabetes Care. 2007;30(6):1406-11. doi:10.2337/dc061458. [PubMed: 17384340 ].

35. Heo HJ, Kim DO, Shin SC, Kim MJ, Kim BG, Shin DH. Effect of antioxidant flavanone, naringenin, from Citrus junoson neuroprotection.J Agric Food Chem. 2004;52(6):1520-5. doi: 10.1021/jf035079g. [PubMed: 15030205]. 